\title{
Spatial genetic structure in a Neolitsea sericea population (Lauraceae)
}

\author{
MYONG GI CHUNG*†, MI YOON CHUNG $\dagger$, GAP SOO OH $\uparrow \&$ B. K. EPPERSON $\ddagger$ \\ $\dagger$ Department of Biology, Gyeongsang National University, Chinju 660-701, The Republic of Korea, \\ $\$$ Department of Forestry, Michigan State University, East Lansing, MI 48824, U.S.A.
}

\begin{abstract}
Neolitsea sericea (B1.) Koidz. (Lauraceae) is a dioecious, insect-pollinated, and broad-leaved evergreen tree with bird-dispersed seeds. We used allozyme loci, $F$-statistics, and spatial autocorrelation statistics (Moran's $I$ ) to examine the changes in genetic structure among five age classes within a study population $(60 \mathrm{~m} \times 100 \mathrm{~m}$ area) in southern Korea. No significant differences in expected heterozygosity were found among the age classes. The mean $F$-values averaged over loci were similar among age classes and showed overall conformance of heterozygosities with Hardy-Weinberg proportions. Differences in allelic frequencies among age classes were small (mean $G_{\mathrm{ST}}=0.012$ ), and statistically significant only for one locus ( $P g d-2)$. The mean Moran's $I$-values for each of five age classes indicated essentially random spatial distribution. The homogeneity of genetic structure and genetic diversity among the five age classes may reflect the occurrence of similar reproductive events, year after year. The results may reflect the attractive red drupes of $N$. sericea in that they cause various frugivorous birds to disperse the seed long distances and independently, which in turn may help $N$. sericea maintain higher levels of genetic diversity within populations.
\end{abstract}

Keywords: allozymes, endozoochory, Moran's I, Neolitsea sericea, seed dispersal, spatial genetic structure.

\section{Introduction}

Spatial genetic structure among sexually reproduced individuals within plant populations is determined primarily by the effects of such factors as limited seed and pollen dispersal, density, colonization history, isolation into small patches, differential mortality, and potentially, microenvironmental selection (Levin \& Kerster, 1974; Epperson, 1993). Some of these genetic and demographic factors, such as localized gene flow from neighbouring parents, past major reproductive events, and selection, may be detected as genetic differences among age classes (Ritland et al., 1989). For example, genetic correlations among progeny, spatially clustered near their maternal parent because of limited seed dispersal, correspond to substantial spatially localized and temporal genetic structure (e.g. Perry \& Knowles, 1991; Schnabel et al., 1991; Berg \& Hamrick, 1994; Geburek \& Tripp-Knowles, 1994; Chung \& Epperson, 2000). In contrast, if seeds are widely and independently dispersed only weak spatial genetic structure will result (e.g. Dewey \& Heywood, 1988; Loiselle et al., 1995; Chung et al., 1999, 2000).

*Correspondence. E-mail: mgchung@nongae.gsnu.ac.kr
Recent studies of genetic structure in plant populations have addressed differences in genetic structure at various life stages or age classes, and have sometimes revealed striking changes in structure resulting from such demographic processes as changes in density (e.g. thinning processes independent of genotypes) and the effects of past major reproductive events by different source trees (e.g. Epperson \& Alvarez-Buylla, 1997; Kitamura et al., 1997a,b). However, there are few studies of the spatial distribution of genetic variation in different age or size classes of woody plants and herbaceous perennials (Hossaert-McKey et al., 1996; Leonardi et al., 1996; Epperson \& Alvarez-Buylla, 1997; Kitamura et al., 1997a,b).

A large number of genotypes in a population of Neolitsea sericea (B1.) Koidz. (Lauraceae) was sampled in this study in order to dissect the dynamic aspects of genetic changes in spatial structure at different age classes. Neolitsea sericea is a dioecious, broad-leaved woody species. It is distributed through southern China and Japan (western region to Chiba Pref. of Honshu, Shikoku, Kyushu, and Ryukyu Islands), and occurs in a few localities in the southern coastal area of the Korean Peninsula. Neolitsea sericea flowers in October and November, is pollinated by various small insects 
(Yumoto, 1987), with individual female plants typically producing hundreds of fruits each year (M.G. Chung, pers. obs.). It takes about one year for seeds to become fully ripened (flowers and fruits coexist from October to November). The red drupes (diameter $\approx 1 \mathrm{~cm}$ ) of $N$. sericea contain a single large seed which is usually dispersed by birds (M.G. Chung \& M.Y. Chung, pers. obs.).

Most populations of $N$. sericea in Japan and Korea are isolated because their habitats are narrowly distributed. The areas of populations vary from $\approx 500 \mathrm{~m}^{2}$ to several hectares (M.G. Chung, pers. obs.). Neolitsea sericea occurs in well-drained, rocky and humus soils on rocky slopes in a few localities in southern Korea. Several local populations in early regenerative stages characterized by substantial mixing of seedlings and juveniles with a few adults ('gaps' or sink populations) were also found in the vicinity of $N$. sericea-dominant canopy forest stands. In addition, numerous seedlings and juveniles (most aged $<5 \mathrm{yr}$ ) are often found scattered far from the possible maternal trees $(\approx 480 \mathrm{~m}$ at Hakdongri on Keojae Island and $680 \mathrm{~m}$ Naechori on Oenaro Island, southern Korea; M.G. Chung, unpubl. data), suggesting that seeds are dispersed over long distances by birds. We have observed that some of the birds that disperse $N$. sericea consume the fruits and drop seeds in the immediate vicinity of the female plants while others take the fruit elsewhere (M.G. Chung \& M.Y. Chung, pers. obs.). Because of the type of seed dispersal, we may expect that spatial genetic structuring in populations of $N$. sericea is weak. In this paper, we examine in detail the spatial genetic structure in five age classes within a study population consisting of multiple age classes.

\section{Materials and methods}

In February 1998, all 628 individuals (Fig. 1) were mapped and leaf samples collected within a $60 \mathrm{~m} \times 100 \mathrm{~m}$ area (altitude $15-40 \mathrm{~m}$ a.s.l., south eastwest, $6 \%$ gradient) at Hakdongri, Keojae Island, Gyeongsangnam Province, southern Korea. The area is a Camellia japonica-dominant, broad-leaved-evergreen forest, with a low density of Pinus thunbergii Parl. and other deciduous trees (e.g. oaks and maples). There are two Neolitsea-dominant forests nearby the study

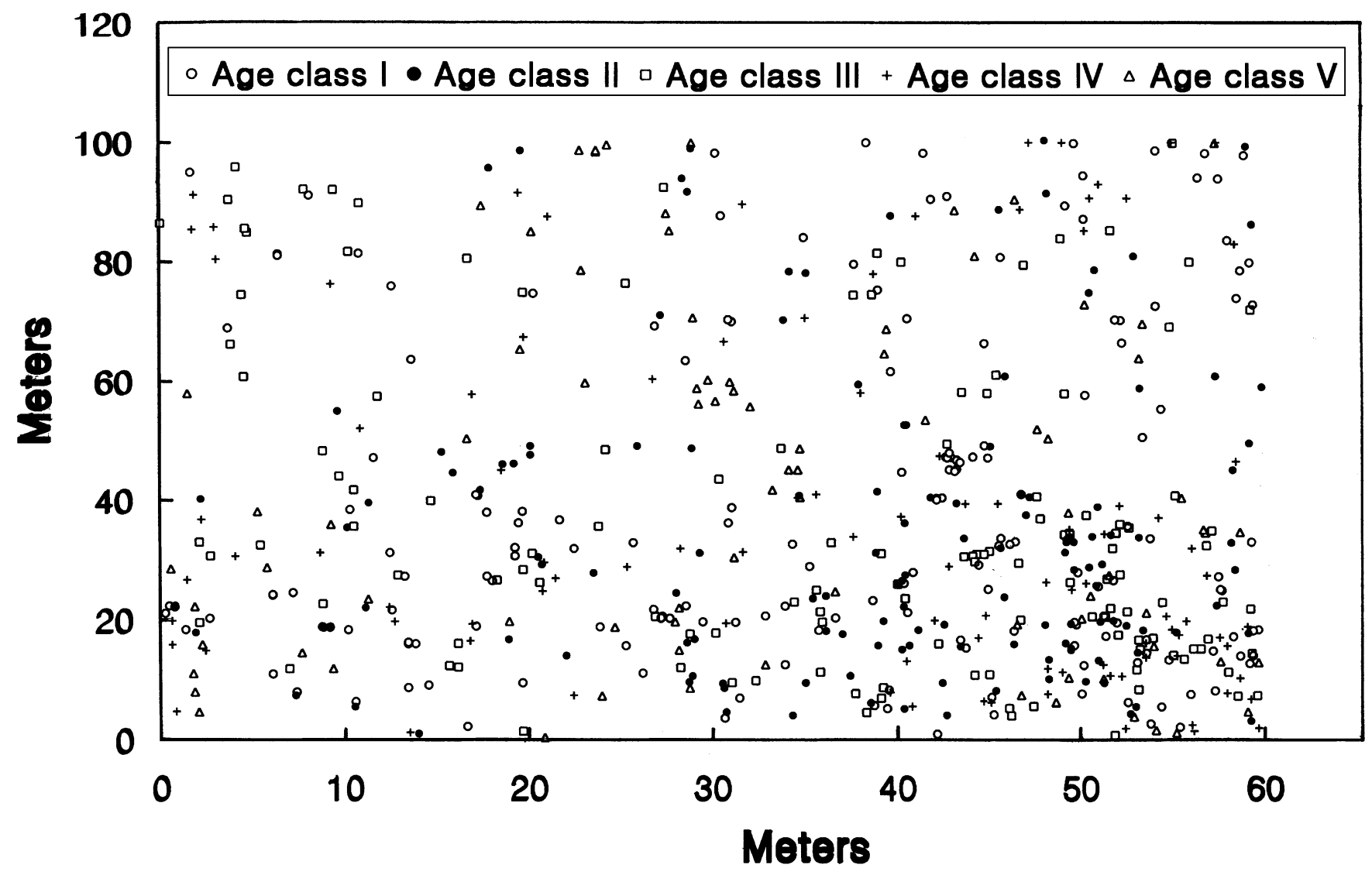

Fig. 1 Spatial distribution of Neolitsea sericea trees within the study plot. Trees with different age are represented by different symbols in the map. The definition of each age class is described in the text and Table 1.

(C) The Genetical Society of Great Britain, Heredity, 85, 490-497. 
population (one is located $\approx 330 \mathrm{~m}$ to the north, and the other $\approx 430 \mathrm{~m}$ to the south, near the coast) each comprising several hundred adults (M.G. Chung, unpubl. data). The population has no recorded history of fire disturbance and there is no evidence of trees having been planted. Ages of individuals were determined by counting annual rings (e.g. based on cores taken by an increment borer for adults and thin transverse sections of stems and leaf scars for juveniles). Individuals were then classified into five age classes which may represent any natural differentiation of cohorts: age class I (seedlings, 180 individuals); age class II (2-3 yr juveniles, 136 individuals); age class III (4-5 yr juveniles, 129 individuals); age class IV (6-7 yr juveniles, 99 individuals); and age class V (8-17 $\mathrm{yr}$ juveniles and five adults, 84 individuals). One leaf per individual was stored at $4^{\circ} \mathrm{C}$ until protein extraction.

Leaves were cut finely, and crushed with a mortar and pestle. A potassium phosphate extraction buffer (Mitton et al., 1979) was added and the crushed extract absorbed onto $4 \mathrm{~mm} \times 6 \mathrm{~mm}$ Whatman $3 \mathrm{MM}$ chromatography paper wicks, and stored at $-70^{\circ} \mathrm{C}$ until needed for electrophoretic analysis. Electrophoresis was performed using $10 \%$ starch gels. Twenty putative loci for $N$. sericea from nine enzyme systems were resolved using two electrophoretic buffer systems. A Poulik buffer system, a modification (Haufler, 1985) of Soltis et al.'s (1983) 'system 6' was used to resolve alcohol dehydrogenase (Adh), diaphorase (Dia-1, Dia-2, Dia-3, Dia-4), leucine aminopeptidase (Lap-1, Lap-2), phosphoglucomutase (Pgm-1, Pgm-2), phosphoglucoisomerase (Pgi-1, Pgi-2), peroxidase (Per-1, Per-2) and triosephosphate isomerase (Tpi-1, Tpi-2). A discontinuous histidine-citrate buffer system, a modification (Chung \& Kang, 1994) of Soltis et al.'s (1983) 'system 11', was used to resolve 6-phosphogluconate dehydrogenase $(P g d-1, P g d-2)$ and malate dehydrogenase (Mdh-1, Mdh-2, Mdh-3). Stain recipes were taken from Soltis et al. (1983), except for diaphorase (Cheliak \& Pitel, 1984). The genetic basis of allozyme banding patterns was inferred from segregation patterns with reference to typical subunit structure (Weeden \& Wendel, 1989). Putative loci were designated sequentially, with the most anodally migrating isozyme designated 1, the next 2, and so on. Similarly, alleles were designated sequentially with the most anodally migrating alleles designated ' $a$ '.

For all data analyses, each of the five age classes was considered separately. Five standard genetic diversity parameters were estimated using the program POPGENE (Yeh et al., 1999): percentage polymorphic loci; mean number of alleles per polymorphic locus; mean number of alleles per locus; effective number of alleles per locus; and expected heterozygosity or gene diversity. Observed heterozygosity was compared to Hardy-Weinberg
(H-W) expected values using Wright's (1922) fixation index $(F)$, with tests for deviations from zero by $\chi^{2}$ tests (Li \& Horvitz, 1953). Nei's (1977) $G_{\mathrm{ST}}$ (mean from an average of the polymorphic loci) was used to measure the differentiation among the five age classes. In addition, a $\chi^{2}$-statistic was used to detect significant differences in allele frequencies among the age classes for each locus (Workman \& Niswander, 1970).

The spatial distributions of allozyme polymorphisms were analysed separately for age classes I to V using Moran's I-statistics (Sokal \& Oden, 1978). The genotype for each allele at each location was converted into the values $0.0,0.5$, or 1.0 according to the numbers (none, one, or two) of that allele in the genotype (Sokal \& Oden, 1978). Only one allele was considered at diallelic loci because the second allele contributes identical information. Every possible pair of individuals was considered as a 'join' between two individuals and assigned to one of 10 distance classes according to the distance separating the two individuals. The upper and lower bounds for the distance classes were selected so that the numbers of pairs (joins) were equal in each class. Moran's I-statistic (Sokal \& Oden, 1978) was calculated for each of 10 distance classes by:

$I_{k}=N \sum \sum_{i j}\left(W_{i j} Z_{i} Z_{j}\right)\left(W \sum Z_{i}^{2}\right)^{1}$,

where: $N$ is the number of individuals in the age class; $W_{i j}$ are elements of the join or weighting matrix, such that $W_{i j}=1.0$ if the pair of $i$ th and $j$ th individuals are in the distance class $k$ and zero otherwise; $Z_{i}=X_{i}-X$, $Z_{j}=X_{j}-X$; the variables $X_{i}$ and $X_{j}$ are the genotypic scores for the $i$ th and $j$ th individuals, respectively; $X$ is the mean score for all individuals; and $W$ is the sum of all $W_{i j}$ for the distance class. Under the null hypothesis, $H_{\mathrm{o}}$, of a random distribution, $I_{k}$ has an expected value, $\mu_{1}$, equal to $-1 /(N-1)$ and an expected variance, $\mu_{2}$ [computational formula given by Sokal \& Oden (1978) and Cliff \& Ord (1981)]. Thus, the statistic, $\mathrm{SND}_{k}=$ $\left(I_{k}-\mu_{1}\right) / \mu_{2}^{1 / 2}$, is a two-tailed test statistic of $H_{\mathrm{o}}$, and it has an approximate standard normal distribution (Cliff \& Ord, 1981) under $H_{\mathrm{o}}$. Absolute values of $\mathrm{SND}_{k}$ greater than 1.96 and 2.58 are significant at the 0.05 and 0.01 levels, respectively. A significant positive value of $I_{k}$ indicates that the pairs of individuals separated by distances that fall within distance class $k$ have more alleles in common than would be expected by chance, whereas a significant negative value suggests that individuals have fewer alleles in common. Overall significance of individual correlograms was tested using Bonferroni's criteria (Sakai \& Oden, 1983). All calculations and statistical analyses were performed using the SAAP program (v. 4.3) written by D. Wartenberg. 


\section{Results}

Of the 20 loci examined, four ( $M d h-3, P g d-2, P g i-2$, and Pgm-2) were polymorphic, whereas 16 (Adh, Dia-1, Dia-2, Dia-3, Dia-4, Lap-1, Lap-2, Pgm-1, Pgi-1, Per-1, Per-2, Tpi-1, Tpi-2, Pgd-1, Mdh-1, and Mdh-2) were monomorphic. Low levels of gene diversity were found for all age classes (Table 1), with no significant differences among the age classes for expected heterozygosity (Kruskal-Wallis test, $H=0.971, P=0.914$ ).

Three-quarters of the fixation indices were negative, indicating heterozygote excesses within age classes (Table 2). However, among negative $F$-values only that for $M d h-3$ differed significantly from zero. The mean $F$-values over loci were similar among age classes; there were also no significant differences in the fixation indices among age classes $(H=1.089, P=0.896)$ (Table 2$)$. In addition, there was no clear evidence of changes in heterozygosity with ageing. Measures of allozyme differentiation, $G_{\mathrm{ST}}$, among age classes were small, ranging from $0.002(M d h-3)$ to $0.030(P g d-2)$ with a mean of 0.012 (Table 2), and only that for $P g d-2$ was significant $(P<0.001)$.

According to the criteria described above, four alleles were used for single locus spatial autocorrelation anal- ysis. The spatial genetic distributions for age classes I to $\mathrm{V}$ were very similar. Moran's $I$-values were significantly different from the expected values in five $(12.5 \%$, age classes I and V), six (15\%, age class IV), and seven $(17.5 \%$, age classes II and III) of 40 cases (Table 3). For distance one $(\leq 13 \mathrm{~m})$, only two significantly positive cases $\left(P g m-2^{\mathrm{a}}\right.$ in age classes $\mathrm{I}$ and $\left.\mathrm{V}\right)$ were observed, indicating that spatial genetic structure in the study population is weak at most. Moreover, the mean values for each of five age classes indicate essentially random distributions of alleles (Table 3, Fig. 2).

\section{Discussion}

The degree of spatial clustering of sexually reproduced individuals with similar genotypes within a population depends on the combination of many genetic processes (e.g. extent of seed and pollen dispersal, genetic drift, and microhabitat selection) and demographic factors (e.g. past reproductive events, thinning processes, mortality rates, scale of gap formation, and other factors of the regeneration processes) (Harper, 1977; Frankel et al., 1995).

Although the percentage of statistically significant individual Moran's $I$-values in five age classes of
Table 1 Summary of genetic diversity measures for 20 isozyme loci observed in five age classes of a Neolitsea sericea population at Hakdongri, Korea
Table 2 Fixation indices $(F)$ for four polymorphic loci in five age classes and the proportion of among age-class genetic diversity $\left(G_{\mathrm{ST}}\right)$ in a population of Neolitsea sericea (Hakdongri, Korea)

\begin{tabular}{lccccc}
\hline & \multicolumn{5}{c}{ Age class $^{1}$} \\
\cline { 2 - 6 } Parameter & I & II & III & IV & V \\
\hline Sample size & 180 & 136 & 129 & 99 & 84 \\
\% polymorphic loci & 20 & 20 & 20 & 20 & 20 \\
Mean number alleles & 1.20 & 1.20 & 1.20 & 1.20 & 1.20 \\
Mean effective number alleles & 1.14 & 1.12 & 1.11 & 1.13 & 1.11 \\
Mean heterozygosity & & & & & \\
$\quad$ Observed & 0.082 & 0.079 & 0.077 & 0.086 & 0.076 \\
(SE) & $(0.005)$ & $(0.005)$ & $(0.005)$ & $(0.006)$ & $(0.006)$ \\
Expected & 0.081 & 0.072 & 0.070 & 0.077 & 0.067 \\
(SE) & $(0.037)$ & $(0.034)$ & $(0.033)$ & $(0.037)$ & $(0.032)$ \\
\hline
\end{tabular}

${ }^{1}$ Age class I, seedlings (180 individuals); age class II, 2-3 yr juveniles (136 individuals); age class III, 4-5 yr juveniles (129 individuals); age class IV, 6-7 yr juveniles (99 individuals); and age class $\mathrm{V}, 8-17 \mathrm{yr}$ juveniles and five adults (84 individuals).

\begin{tabular}{lcccccc}
\hline & \multicolumn{7}{c}{ Age class } & \\
\cline { 2 - 6 } Locus & I & II & III & IV & V & \multicolumn{1}{c}{$G_{\mathrm{ST}}$} \\
\hline Mdh-3 & $-0.273^{* * *}$ & $-0.226^{* *}$ & $-0.260^{* * *}$ & $-0.249^{* * *}$ & $-0.275^{*}$ & 0.002 \\
Pgd-2 & 0.061 & -0.059 & -0.012 & -0.028 & 0.115 & $0.030^{* * *}$ \\
Pgi-2 & -0.029 & -0.094 & -0.114 & -0.057 & -0.036 & 0.008 \\
Pgm-2 & 0.133 & -0.004 & 0.012 & 0.115 & -0.199 & 0.009 \\
Mean & -0.027 & -0.096 & -0.097 & -0.054 & -0.099 & 0.012 \\
\hline$* P<0.05 ; * * P<0.01 ; * * * P<0.001$. & & &
\end{tabular}


$N$. sericea is somewhat higher than the expected 5\% type I error rate, the overall correlograms clearly indicate that there is essentially no spatial autocorrelation of genotypes. Moreover, although no statistical tests for differences between correlograms have been developed
(Sokal \& Wartenberg, 1983), the results indicate that the spatial genetic distributions in the five age classes are all similar. The homogeneity of genetic structure and genetic diversity among the five age classes suggest that reproductive events at the population level are highly

Table 3 Spatial autocorrelation coefficients (Moran's I) of four alleles in Hakdongri population of Neolitsea sericea for 10 distance classes

Age class I (the expected value, $\mu_{1}=-0.006$ )

\begin{tabular}{|c|c|c|c|c|c|c|c|c|c|c|c|c|}
\hline \multirow[b]{2}{*}{ Allele } & \multicolumn{10}{|c|}{ Distance class (upper bound, m) } & \multirow[b]{2}{*}{$P^{1}$} & \multirow{2}{*}{$\begin{array}{c}\text { Allele } \\
\text { frequency }\end{array}$} \\
\hline & 1(13) & 2(19) & $3(25)$ & 4(31) & $5(37)$ & $6(44)$ & $7(51)$ & $8(61)$ & $9(74)$ & $10(107)$ & & \\
\hline$M d h-2^{\mathrm{a}}$ & 0.02 & -0.03 & $0.03^{*}$ & $0.06 * *$ & -0.01 & $-0.07 * *$ & 0.03 & -0.03 & -0.02 & $-0.05^{*}$ & 0.016 & 0.217 \\
\hline $\operatorname{Pg} d-2^{\mathrm{a}}$ & 0.01 & -0.02 & 0.02 & -0.02 & 0.02 & 0.01 & -0.01 & -0.03 & -0.01 & -0.02 & 1.000 & 0.722 \\
\hline $\operatorname{Pg} i-2^{\mathrm{a}}$ & -0.02 & 0.02 & -0.01 & 0.02 & -0.01 & -0.01 & -0.04 & -0.02 & -0.00 & 0.01 & 0.644 & 0.281 \\
\hline$P g m-2^{\mathrm{a}}$ & $0.04^{*}$ & -0.01 & 0.02 & -0.03 & 0.01 & -0.03 & -0.02 & -0.01 & -0.02 & -0.00 & 0.349 & 0.617 \\
\hline Mean & 0.01 & -0.01 & 0.02 & 0.01 & 0.00 & -0.03 & -0.01 & -0.02 & -0.01 & -0.02 & & \\
\hline
\end{tabular}

Age class II (the expected value, $\mu_{1}=-0.007$ )

\begin{tabular}{|c|c|c|c|c|c|c|c|c|c|c|c|c|}
\hline \multirow[b]{2}{*}{ Allele } & \multicolumn{10}{|c|}{ Distance class (upper bound, m) } & \multirow[b]{2}{*}{$P^{1}$} & \multirow{2}{*}{$\begin{array}{c}\text { Allele } \\
\text { frequency }\end{array}$} \\
\hline & $1(10)$ & 2(16) & $3(21)$ & 4(26) & $5(31)$ & $6(37)$ & 7(44) & $8(52)$ & $9(68)$ & $10(108)$ & & \\
\hline$M d h-2^{\mathrm{a}}$ & -0.03 & 0.01 & -0.02 & -0.01 & 0.01 & -0.00 & -0.04 & -0.03 & $0.05^{*}$ & -0.02 & 0.185 & 0.188 \\
\hline $\operatorname{Pg} d-2^{\mathrm{a}}$ & -0.01 & $0.06^{*}$ & -0.02 & -0.02 & -0.02 & 0.03 & $-0.08 * *$ & 0.00 & 0.00 & -0.02 & 0.064 & 0.824 \\
\hline $\operatorname{Pgi}-2^{\mathrm{a}}$ & 0.03 & $0.09 * *$ & 0.04 & -0.02 & -0.02 & $-0.06 *$ & -0.02 & -0.04 & 0.01 & $-0.07 * *$ & 0.009 & 0.294 \\
\hline$P g m-2^{\mathrm{a}}$ & -0.01 & 0.03 & $-0.11 * *$ & -0.02 & 0.01 & 0.00 & 0.03 & -0.00 & -0.00 & -0.01 & 0.003 & 0.677 \\
\hline Mean & -0.00 & 0.05 & -0.03 & -0.02 & -0.01 & -0.01 & -0.03 & -0.02 & 0.01 & -0.03 & & \\
\hline
\end{tabular}

Age class III (the expected value, $\mu_{1}=-0.008$ )

\begin{tabular}{|c|c|c|c|c|c|c|c|c|c|c|c|c|}
\hline \multirow[b]{2}{*}{ Allele } & \multicolumn{10}{|c|}{ Distance class (upper bound, m) } & \multirow[b]{2}{*}{$P^{1}$} & \multirow{2}{*}{$\begin{array}{c}\text { Allele } \\
\text { frequency }\end{array}$} \\
\hline & $1(11)$ & $2(17)$ & $3(23)$ & $4(29)$ & $5(36)$ & $6(43)$ & $7(51)$ & $8(61)$ & $9(73)$ & $10(107)$ & & \\
\hline$M d h-2^{\mathrm{a}}$ & -0.03 & 0.04 & $0.06^{*}$ & -0.03 & -0.01 & 0.02 & 0.03 & -0.05 & -0.05 & 0.02 & 0.153 & 0.209 \\
\hline$P g d-2^{\mathrm{a}}$ & 0.01 & -0.01 & $0.08 * *$ & -0.02 & -0.01 & $-0.09 * *$ & 0.04 & -0.06 & 0.03 & $-0.06^{*}$ & 0.024 & 0.868 \\
\hline$P g i-2^{\mathrm{a}}$ & 0.02 & $0.07 * *$ & 0.01 & 0.01 & 0.03 & -0.01 & -0.03 & $-0.07 *$ & $-0.06^{*}$ & -0.04 & 0.079 & 0.264 \\
\hline$P g m-2^{\mathrm{a}}$ & 0.00 & -0.04 & -0.00 & -0.06 & 0.02 & -0.02 & 0.02 & 0.02 & -0.02 & 0.01 & 0.514 & 0.640 \\
\hline Mean & 0.00 & -0.01 & 0.04 & -0.02 & 0.01 & -0.02 & 0.01 & -0.04 & -0.03 & -0.02 & & \\
\hline
\end{tabular}

Age class IV (the expected value, $\mu_{1}=-0.012$ )

\begin{tabular}{|c|c|c|c|c|c|c|c|c|c|c|c|c|}
\hline \multirow[b]{2}{*}{ Allele } & \multicolumn{10}{|c|}{ Distance class (upper bound, m) } & \multirow[b]{2}{*}{$P^{1}$} & \multirow{2}{*}{$\begin{array}{l}\text { Allele } \\
\text { frequency }\end{array}$} \\
\hline & $1(11)$ & 2(19) & $3(26)$ & $4(33)$ & $5(41)$ & $6(49)$ & $7(57)$ & $8(68)$ & $9(81)$ & $10(111)$ & & \\
\hline$M d h-2^{\mathrm{a}}$ & -0.01 & 0.00 & -0.01 & 0.04 & -0.02 & -0.00 & -0.03 & -0.04 & 0.06 & $-0.09^{*}$ & 0.209 & 0.313 \\
\hline$P g d-2^{\mathrm{a}}$ & -0.01 & -0.02 & -0.02 & 0.04 & 0.03 & -0.03 & -0.03 & -0.08 & 0.01 & -0.01 & 0.548 & 0.884 \\
\hline$P g i-2^{\mathrm{a}}$ & -0.02 & $-0.09 *$ & $0.06^{*}$ & -0.00 & -0.03 & -0.01 & 0.00 & -0.01 & -0.02 & 0.01 & 0.262 & 0.323 \\
\hline$P g m-2^{\mathrm{a}}$ & 0.01 & 0.01 & $-0.08^{*}$ & $-0.09 *$ & $0.11^{* *}$ & -0.02 & 0.03 & -0.03 & 0.02 & -0.05 & 0.022 & 0.631 \\
\hline Mean & -0.01 & -0.02 & -0.01 & -0.00 & 0.02 & -0.01 & -0.00 & -0.04 & 0.02 & -0.03 & & \\
\hline
\end{tabular}


Table 3 (Continued)

Age class V (the expected value, $\mu_{1}=-0.012$ )

\begin{tabular}{|c|c|c|c|c|c|c|c|c|c|c|c|c|}
\hline \multirow[b]{2}{*}{ Allele } & \multicolumn{10}{|c|}{ Distance class (upper bound, m) } & \multirow[b]{2}{*}{$P^{1}$} & \multirow{2}{*}{$\begin{array}{c}\text { Allele } \\
\text { frequency }\end{array}$} \\
\hline & 1(14) & $2(23)$ & 3(29) & $4(35)$ & $5(41)$ & $6(48)$ & $7(54)$ & $8(62)$ & $9(77)$ & $10(110)$ & & \\
\hline$M d h-2^{\mathrm{a}}$ & -0.05 & -0.04 & -0.03 & -0.03 & 0.02 & -0.02 & -0.01 & -0.00 & 0.02 & 0.01 & 1.000 & 0.220 \\
\hline$P g d-2^{\mathrm{a}}$ & -0.01 & -0.06 & 0.03 & -0.04 & 0.03 & $-0.09 *$ & -0.01 & 0.03 & 0.01 & -0.01 & 0.482 & 0.887 \\
\hline$P g i-2^{\mathrm{a}}$ & -0.03 & -0.05 & 0.02 & -0.03 & -0.01 & -0.04 & $0.08 *$ & -0.04 & -0.05 & 0.02 & 0.301 & 0.304 \\
\hline $\operatorname{Pgm}-2^{\mathrm{a}}$ & $0.10^{*}$ & -0.07 & $-0.14 * *$ & -0.09 & 0.05 & $0.09 *$ & -0.00 & 0.03 & -0.02 & -0.07 & 0.048 & 0.750 \\
\hline Mean & 0.00 & -0.06 & -0.03 & -0.05 & 0.02 & -0.02 & 0.02 & 0.01 & -0.01 & -0.02 & & \\
\hline
\end{tabular}

${ }^{1}$ Overall correlogram significance (Bonferroni approximation).

Number in parentheses indicates upper bound $(\mathrm{m}) .{ }^{*} P<0.05 ;{ }^{*} P<0.01$.

Fig. 2 Correlograms for the Hakdongri population of Neolitsea sericea using mean value of Moran's $I$ for alleles at four loci and 10 distance intervals.

Symxbols are same as Fig. 1. The actual upper distance limits are given in Table 3.

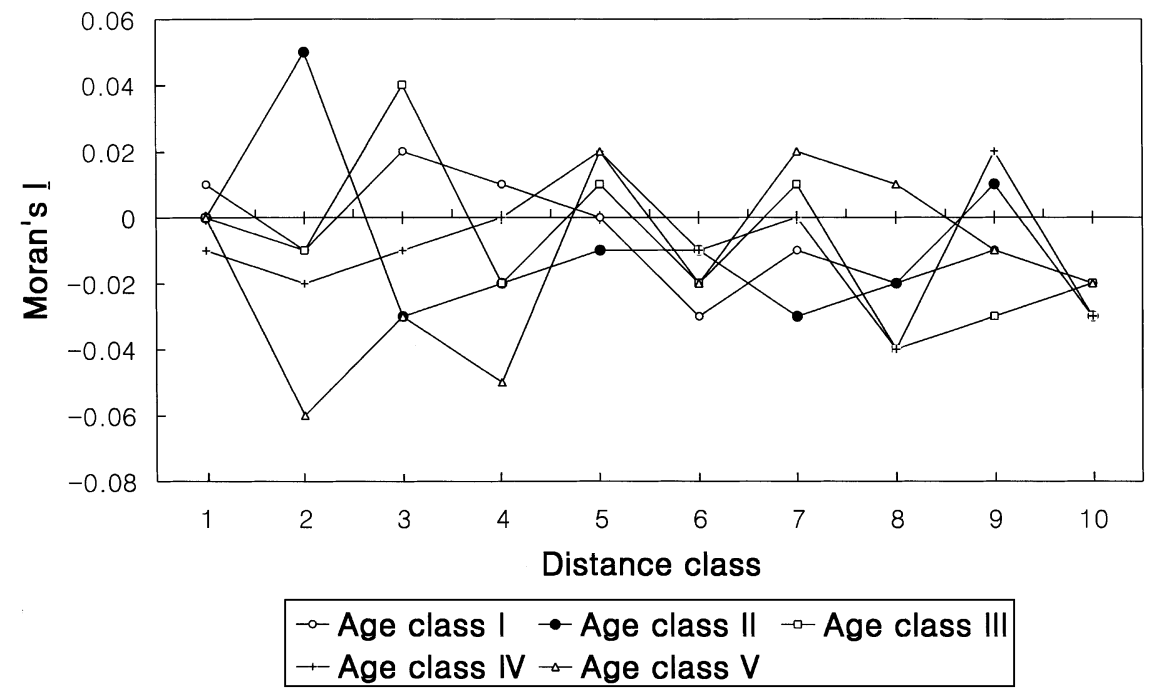

similar from year to year, in terms of genetics. Although it appears that reproduction of any individual does vary somewhat from year to year, there appear to be enough reproductive individuals each year that genetic effects average out.

In seed plants, pollen dispersal is solely by migration, whereas seed or fruit dispersal could result in both migration and colonization events (Hamrick \& Nason, 1996). Because gene movement in seed plants is sequential (a two-step process via pollen then by seed), observed genetic structure may be influenced most strongly by limited seed dispersal compared to pollen movement. Family structure can result solely by limited seed dispersal (J. L. Hamrick, pers. comm.), and limited seed dispersal may lead to genetically distinct seed shadows among maternal plants. Moreover, if pollen dispersal is also restricted, this could eventually cause the buildup of more intense genetic structure within populations over many generations (Linhart et al., 1981; Hamrick \& Nason, 1996). One important aspect of seed movement is its role in the initial founding of a population. When populations are founded by longdistance, wind-dispersed or bird-dispersed seed, in many cases the initial spatial distribution of genetic variation may be nearly random, because at long distances the dispersal function on distance is 'flat'; hence, the resting places of seeds become nearly independent of their starting places (Epperson, 1990). Our results may support these theoretical expectations. The age of a population (i.e. how many cycles of regeneration have occurred since population establishment) is also important. Older populations can have much stronger spatial genetic structure because of increased genetic isolationby-distance over cycles of regenerating (e.g. Epperson, 1993). This is not the case for the study population. Most seedlings and juveniles of $N$. sericea occur in new gaps, seemingly established during past decade from maternal trees in nearby two older stands (source populations), because only the five adults exist in the study population area. In other words, the study

(C) The Genetical Society of Great Britain, Heredity, 85, 490-497. 
population, in general, has been colonized by offspring of recent reproductive events. It is suggested that the genotypes of the founding seeds (deposited by birds from vicinity of the study population) were essentially randomly distributed spatially from year by year.

Simple summary measures of seed dispersal distances are insufficient for determining the amount of spatial structure among seedlings or young plants. For example, the results of our fine-scale spatial analysis differed from those of Epperson \& Alvarez-Buylla (1997) for a population of Cecropia obtusifolia (Cecropiaceae), even though the two species share several similarities in reproductive biology (e.g. dioecy, and seed dispersal by various frugivores). Cecropia obtusifolia showed very strong genetic spatial autocorrelations among seedlings concentrated within canopy gaps, but structure was very weak in juveniles and adults, as a consequence of thinning processes (as seedlings mature and were thinned out). However, there are at least two important differences in the demographics of the two study populations. First, the study population of C. obtusifolia was old and stable, wherein the forest was closedcanopy; $C$. obtusifolia individuals were distributed densely and seedlings grew only in recent small canopy gaps. Secondly, and perhaps more important, entire fruits containing many seeds (mostly half-sibs) of C. obtusifolia are deposited into gaps. In contrast, individual seeds of $N$. sericea may move more independently. The fruits of $N$. sericea are quite large $(\approx 1 \mathrm{~cm}$ diameter), and birds can harvest few at a time.

Overall, the autocorrelation statistics obtained for $N$. sericea are similar to those obtained for most other insect-pollinated woody species with seed dispersal by birds. For example, Dewey \& Heywood (1988) used five alleles and Moran's $I$ to examine fine-scale structure in a population of the shrub Psychotria nervosa (Rubiaceae) in south Florida. None of the nearest-neighbour pairs had significant Moran's I-values for five alleles. More recently, however, Loiselle et al. (1995) analysed finescale genetic structure in a population of Psychotria officinalis in Costa Rica to estimate coancestries (Cockerham, 1969) using 26 alleles. They found a significant positive autocorrelation among individuals located up to $5 \mathrm{~m}$ apart but no significant genetic relatedness beyond that inter plant distance within the population. They suggested that although some proportion of seed dispersal may be localized, there is substantial mixing of seed shadows as a result of fruit removal by birds. In Korea, Chung et al. (1999, 2000) examined fine-scale genetic structure using nine and 12 alleles and Moran's I-statistics in earlier stage populations of two Rhus (Anacardiaceae) species ( $R$. trichocarpa and $R$. javanica), dioecious trees that are insect-pollinated, with seeds that are dispersed by birds. They also detected only $10(11 \%)$ and $13(10.8 \%)$ of 90 and 120 cases of significant Moran's $I$-values in populations of $R$. trichocarpa and $R$. javanica, respectively, indicating little spatial genetic structuring among individuals in populations.

In summary, the present study of spatial and demographic genetics revealed a lack of genetic structure in an initially regenerative local population, and shows that this is a consequence of extensive gene flow through widespread, and perhaps nearly independent, dispersal of seed by birds. Given the available information, it is suggested that the coevolution between $N$. sericea, with its attractive red drupes containing an edible portion, and associated birds (endozoochory) is an important syndrome for maintaining genetic diversity within populations and for providing opportunities of regenerating the species in new gaps. Further understanding of how the observed spatial genetic structure in age classes of $N$. sericea is determined would require comprehensive studies of extent and patterns of colonization and migration, variation in reproductive events year by year, and patterns of seedling and juvenile survival at local populations in a metapopulation of $N$. sericea. These studies are now in progress in Naechori on Oenaro Island, southern Korea.

\section{Acknowledgements}

The authors are grateful to the following persons for their assistance in the field studies: N.W. Lee and S.K. Lee. This research was supported by a grant from the Korea Science and Engineering Foundation (KOSEF 96-0500-006-2) to MGC and a postdoctoral award from the KOSEF from 1998 to 1999 to GSO.

\section{References}

BERG, E. E. AND HAMRICK, J. L. 1994. Spatial and genetic structure of two sandhills oaks: Quercus laevis and Quercus margaretta (Fagaceae). Am. J. Bot., 81, 7-14.

CHELIAK, W. M. AND PITEL, J. P. 1984. Technique for starch gel electrophoresis of enzyme from forest tree species. Information Report PI-X-42. Petawawa National Forestry Institute, Agriculture Canada, Canadian Florestry Service, pp. 1-49. Chalk River, Ontario.

CHUNG, M. G. AND EPPERSON, B. K. 2000. Spatial genetic structure of allozyme polymorphisms in a population of Eurya japonica (Theaceae). Silvae Genet., 49, 1-4.

CHUNG, M. G. AND KANG, s. S. 1994. Genetic variation and population structure in Korean populations of Eurya japonica (Theaceae). Am. J. Bot., 81, 1077-1082.

CHUNG, M. G., ChUNG, J. M. AND EPPERSON, B. K. 1999. Spatial genetic structure of allozyme polymorphisms within populations of Rhus trichocarpa (Anacardiaceae). Silvae Genet., 48, 223-227. 
CHUNG, M. G., CHUNG, J. M., CHUNG, M. Y. AND EPPERSON, B. K. 2000. Spatial distribution of allozyme polymorphisms following clonal and sexual reproduction in populations of Rhus javanica (Anacardiaceae). Heredity, 84, 178-185.

ClifF, A. D. AND ORD, J. K. 1981. Spatial Processes-Methods and Applications. Pion, London.

COCKERHAM, C. C. 1969. Variance of gene frequencies. Evolution, 23, 72-84.

DEWEY, S. E. AND HEYWOOD, J. S. 1988. Spatial genetic structure in a population of Psychotria nervosa. I. Distribution of genotypes. Evolution, 42, 834-838.

EPPERSON, B. K. 1990. Spatial autocorrelation of genotypes under directional selection. Genetics, 124, 757-771.

EPPERSON, B. K. 1993. Recent advances in correlation analysis of spatial patterns of genetic variation. Evol. Biol., 27, 95-155.

EPPERSON, B. K. AND ALVAREZ-BUYLlA, E. R. 1997. Limited seed dispersal and genetic structure in life stages of Cecropia obtusifolia. Evolution, 51, 275-282.

FRANKEL, O. H., BROWN, A. H. D. AND BURDON, J. J. 1995. The Conservation of Plant Biodiversity. Cambridge University Press, Cambridge.

GEBUREK, T. AND TRIPP-KNOWLES, P. 1994. Genetic architecture in bur oak, Quercus macrocarpa (Fagaceae), inferred by means of spatial autocorrelation analysis. Pl. Syst. Evol., 189, 63-74.

HAMRICK, J. L. AND NASON, J. D. 1996. Consequences of dispersal in plants. In: Rhodes, O. E. Jr, Chesser, R. K. and Smith, M. H. (eds) Population Dynamics in Ecological Space and Time, pp. 203-206. University of Chicago Press, Chicago, IL.

HARPer, J. L. 1977. Population Biology of Plants. Academic Press, London.

HAUFLER, C. H. 1985. Enzyme variability and modes of evolution in Bommeria (Pteridaceae). Syst. Bot., 10, 92-104.

HOSSAERT-MCKEY, M., VALERO, M., MAGDA, D., JARRY, M., CUGUEN, J. AND VERNET, P. 1996. The evolving genetic history of a population of Lathyrus sylvestris: evidence from temporal and spatial genetic structure. Evolution, 50, 1808-1821.

KITAMURA, K., SHIMADA, K., NAKASHIMA, K. AND KAWANO, S. 1997a. Demographic genetics of the Japanese beech, Fagus crenata, at Ogawa Forest Preserve, Ibaraki, Central Honshu, Japan. I. Spatial genetic structuring in local populations. Pl. Sp. Biol., 12, 107-135.

KITAMURA, K., SHIMADA, K., NAKASHIMA, K. AND KAWANO, S. 1997b. Demographic genetics of the Japanese beech, Fagus crenata, at Ogawa Forest Preserve, Ibaraki, Central Honshu, Japan. II. Genetic structuring among size-classes in local populations. Pl. Sp. Biol., 12, 137-155.

LEONARDI, S., RADDI, S. AND BORGHETTI, M. 1996. Spatial autocorrelation of allozyme traits in a Norway spruce (Picea abies) population. Can. J. For. Res., 26, 63-71.

LEVIN, D. A. AND KERSTER, H. W. 1974. Gene flow in seed plants. Evol. Biol., 7, 139-220.
LI, C. C. AND HORVITZ, D. G. 1953. Some methods of estimating the breeding coefficient. Am. J. Hum. Genet., 5, 107-117.

LINHART, Y. B., MITTON, J. B., STURGEON, K. B. AND DAVIS, M. L. 1981. Genetic variation in space and time in a population of ponderosa pine. Heredity, 46, 407-426.

LOISELle, B. A., SORK, V. L., NASON, J. AND GRAHAM, C. 1995. Spatial genetic structure of a tropical understorey shrub, Psychotria officinalis (Rubiaceae). Am. J. Bot., 82, 14201425.

MITTON, J. B., LINHART, Y. B., STURGEON, K. B. AND HAMRICK, J. L. 1979. Allozyme polymorphisms detected in mature needle tissue of ponderosa pine. J. Hered., 70, 86-89.

NEI, M. 1977. F-statistics and analysis of gene diversity in subdivided populations. Ann. Hum. Genet., 41, 225-233.

PERRY, D. J. AND KNOWLES, P. 1991. Spatial genetic structure within three sugar maple (Acer saccharum Marsh.) stands. Heredity, 66, 137-142.

RITLAND, K. 1989. Gene diversity and the genetic demography of plant populations. In: Brown, A. H. D., Clegg, M. T., Kahler, A. L. and Weir, B. S. (eds) Plant Population Genetics, Breeding, and Genetic Resources, pp. 181-199. Sinauer, Sunderland, MA.

SAKAI, A. K. AND ODEN, N. L. 1983. Spatial pattern of sex expression in silver maple (Acer saccharium L.): Morista's index and spatial autocorrelation. Am. Nat., 122, 489-508.

SCHNABEL, A. R., LAUSHMAN, R. H. AND HAMRICK, J. L. 1991. Comparative genetic structure of two co-occurring tree species, Maclura pomifera (Moraceae) and Gleditsia triacanthos (Leguminosae). Heredity, 67, 357-364.

SOKAL, R. R. AND ODEN, N. L. 1978. Spatial autocorrelation in biology. 1. Methodology. Biol. J. Linn. Soc., 10, 199-249.

SOKAL, R. R. AND WARTENBERG, D. 1983. A test of spatial autocorrelation analysis using an isolation-by-distance model. Genetics, 105, 219-237.

SOlTIS, D. E., HAUFLER, C. H., DARROW, D. C. AND GASTONY, G. J. 1983. Starch gel electrophoresis of ferns: a compilation of grinding buffers, gel and electrode buffers, and staining schedules. Am. Fern J., 73, 9-27.

WEEDEN, N. F. AND WENDEL, J. F. 1989. Genetics of plant isozymes. In: Soltis, D. E. and Soltis, P. S. (eds) Isozymes in Plant Biology, pp. 46-72. Dioscorides Press, Portland, OR.

WORKMAN, P. L. AND NISWANDER, J. D. 1970. Population studies on southwestern Indian tribes. II. Local genetic differentiation in the Papago. Am. J. Hum. Genet., 22, 24-49.

WRIGHT, s. 1922. Coefficients of inbreeding and relationship. Am. Nat., 56, 330-338.

YEH, F. C., YANG, R.-C. AND BOYLE, T. B. J. 1999. POPGENE v. 1.31, microsoft window-based freeware for population genetic analysis. University of Alberta and Centre for International Forestry Research, Canada.

YUмото, т. 1987. Pollination systems of a warm temperature evergreen broad-leaved forest in Yakushima Island. Ecol. Res., 2, 133-145. 